\title{
ETOS KERJA : KETELADANAN MASYARAKAT BANYUMAS AWAL ABAD XX
}

\author{
Oleh : HY Agus Murdiyastomo*
}

\begin{abstract}
Abstrak
Daerah Banyumas bagian selatan dikenal sebagai daerah yang subur penghasil padi, dan mempunyai kepadatan penduduk yang cukup tinggi. Kesuburan tanah ini kemudian menarik para investor untuk menanamkan modalnya di daerah ini dengan membuka perkebunan tebu, dan pabrik gula. Masuknya usaha tersebut pada akhirnya menyerobot lahan tanaman pangan, karena syarat penanaman tebu kurang lebih sama dengan syarat penanaman padi. Usaha perkebunan dan berdirinya pabrik gula, telah menjadi daya tarik bagi penduduk dari luar untuk turut mengais rejeki di Banyumas. Dengan demikian beban daerah ini semakin berat karena meningkatnya jumlah penduduk pada setiap tahunnya. Penggusuran lahan pertanian tentu mengurangi produksi pangan per tahun, yang pada akhirnya mengancam kesejahteraan penduduk. Walaupun tekanan semakin menghimpit, tetapi hidup harus tetap berlangsung, dan bagaimana usaha penduduk Karesidenan Banyumas menanggapi perkembangan situasi itu, dan dapat bertahan bahkan keluar dari tekanan ekonomi.

Untuk merunut bagaimana penduduk Banyumas dapat bertahan hidup, dan bahkan keluar dari tekanan ekonomi, maka digunakan metode sejarah kritis, dengan mengkaji dokumen-dokumen yang berhasil dikumpulkan, ditunjang pula dengan bahan pustaka yang berhubungan dengan persoalan yang dikaji. Pengkajian terhadap persoalan yang hendak dipecahkan dilakukan dengan pendekatan ekologis, seperti yang dilakukan oleh Geertz, dan menggali akar budaya Banyumas dengan pendekatan etnografis.

Hasil kajian menunjukan bahwa Masyarakat Banyumas mampu bertahan dari tekanan ekonomi karena masyarakat Banyumas memiliki etos kerja yang tinggi. Kerja bagi masyarakat Banyumas bukan semata-mata untuk memperoleh penghasilan, tetapi kerja dilandasi dengan falsafah yang justru muncul dari stereotype orang Banyumas, yaitu terus terang dan apa adanya yang dalam dialek banyumas disebut dengan "cablaka", Hal ini pantas dikembangkan dalam rangka membangkitkan etos kerja yang dilandasi semangat nasionalisme, demi meraih Indonesia yang makmur dan sejahtera.
\end{abstract}

Kata Kunci: Banyumas, “cablaka”, etos kerja, dan semangat nasionalisme.

\section{A. Pendahuluan}

Secara geografis daerah Banyumas terletak di Jawa tengah, bagian barat berbatasan langsung dengan wilayah propinsi Jawa Barat, selatan berbatasan

\footnotetext{
${ }^{*}$ Staf pengajar pada Prodi Sejarah, Jurusan Pendidikan Sejarah FISE UNY
} 
dengan pantai samudera Hindia, di timur berbatasan dengan daerah Bagelen, sedang bagian utara berbatasan dengan daerah Pekalongan, Tegal, dan Cirebon. Secara administrative daerah ini merupakan sebuah wilayah Karesidenan, yang terdiri dari lima kabupaten, yaitu Purbalingga, Banjarnegara, Cilacap, Banyumas dan Purwokerto, yang seluruhnya meliputi areal seluas 3808 pal Persegi (Arsip Banjoemas No. 20.16). Akan tetapi pada tahun 1936 pemerintah kolonial menghapus kabupaten Purwokerto, dan wilayahnya digabungkan dengan kabupaten Banyumas, sehingga Karesidenan Banyumas terhitung mulai tanggal 1 Januari 1936 hanya memiliki 4 kabupaten saja yaitu Banyumas, Cilacap, Purbalingga, dan Banjarnegara (Dina Dwikurniarini, 1999 : 32).

Daerah yang membujur dari barat ke timur ini Sebagian wilayahnya merupakan daerah yang bergunung-gunung, terutama dibagian utara dengan adanya Gunung Slamet dan Gunung Prahu. Adanya gunung berapi inilah yang menyebabkan daerah Banyumas pada umumnya menjadi daerah yang subur, mengingat di wilayah ini tanahnya kaya akan sedimen dan curah hujan yang cukup. Selain itu wilayah ini terbelah oleh aliran Sungai Serayu, yang merupakan muara dari sungai-sungai lain yang lebih kecil. Keberadaan aliran sungai Serayu ini melengkapi potensi alam karesidenan Banyumas, dan oleh karenanya di sepanjang aliran sungai itulah banyak terdapat pemukiman penduduk. Lingkungan alam seperti tersebut di atas, memungkinkan penduduk di daerah Banyumas mengembangkan system pertanian sawah, yang kemudian menjadi mata pencaharian pokok penduduk.

Teori Involusi Pertanian dan kemiskinan bersama yang dikemukakan oleh Geertz banyak menuai kritik, tetapi tidak dapat dipungkiri bahwa Jawa pada umumnya termasuk daerah Banyumas mempunyai kepadatan penduduk yang tinggi. Padatnya penduduk di Jawa oleh Geertz dipandang semata-mata disebabkan oleh pola tanggapan terhadap pertambahan penduduk pada system sawah. Tegasnya peningkatan produksi pertanian dilakukan dengan cara meningkatkan masukan tenaga kerja pada lahan yang sama (Hiroyosi Kano, 1986 : 17-18).

Pertambahan jumlah penduduk berarti semakin banyak pula tenaga kerja, dan sawah memang dapat menampung berapapun jumlah tenaga kerja yang ada. Akan tetapi masukan tenaga kerja pada lahan pertanian sebagai usaha peningkatan produksi tentu ada batasnya, pada puncaknya lahan yang luasnya tidak pernah bertambah, masukan tenaga kerja tidak akan berarti 
meningkatnya produksi. Pada akhirnya hasil produksi yang tetap akan semakin banyak terbagi, sehingga setiap tenaga kerja akan semakin sedikit menerima bagian dari produksi yang dihasilkan.

Di sisi yang lain system bagi waris yang berlaku adalah system yang mengikuti hukum adat setempat. Dalam adat Jawa pada umumnya setiap anak akan mendapat bagian tanah dari orang tuanya. Sistem ini mengakibatkan penguasaan tanah keluarga dari satu generasi ke generasi berikutnya akan semakin sempit. Dengan demikian semakin sedikit pula hasil produksi yang diperoleh, sehingga pada puncaknya tidak akan mencukupi kebutuhan pangan keluarga. Akibat dari sempitnya lahan, yang tidak memungkinkan lagi untuk menopang kelangsungan hidup keluarga, maka tanah akan berpindah tangan. Hal ini kemudian menambah jumlah angka petani tanpa tanah atau petani penggarap, bahkan buruh tani.

Tahun 1870 pemerintah Kolonial mulai mengijinkan kaum swasta membuka usaha di Hindia Belanda setelah system tanampaksa banyak mendapat kritik. Kesuburan tanah dan tersedianya tenaga kerja di Jawa menarik minat pengusaha untuk menanamkan modalnya. Demikian pula Daerah Banyumas tidak luput dari perhatian mereka, di Banyumas kemudian banyak dibuka usaha perkebunan. Dari sekian banyak perkebunan diantaranya adalah perkebunan tebu dan industri gula. Tanaman tebu mempunyai karakteristik yang sama dengan tanaman padi, sehingga cocok di tanam di lahan persawahan. Akibatnya usaha perkebunan tebu "menggusur” penanaman tanaman pangan khususnya padi. Penggusuran lahan pertanian tentu mengurangi produksi pangan per tahun, yang pada akhirnya mengancam kesejahteraan penduduk. Walaupun tekanan semakin menghimpit, tetapi hidup harus tetap berlangsung, dan bagaimana usaha penduduk Karesidenan Banyumas menanggapi perkembangan situasi itu, dan dapat bertahan bahkan keluar dari tekanan ekonomi.

\section{B. Lingkungan dan Perubahannya}

Persoalan lingkungan selalu dipandang dari sisi kepentingan manusia, sehingga kelestarian alam lingkungan sangat dipengaruhi oleh kepentingan manusia. Kelestarian alam dengan demikian sangat rawan mengingat eksploitasi yang dilakukan manusia kadang tidak memperhitungkan keseimbangan unsur-unsur alam seperti tumbuh-tumbuhan dan binatang, tanah, air, dan udara. Kerusakan alam akan terjadi apabila satu atau lebih dari 
keempat unsur lingkungan rusak dan tidak berfungsi seperti seharusnya. Kerusakan lingkungan pada akhirnya akan memperlemah daya dukung alam bagi kelangsungan hidup manusia.

Karesidenan Banyumas mempunyai wilayah yang cukup luas, bahkan terluas dibanding dengan daerah lain di Jawa Tengah. Wilayah yang membentang dari barat ke timur ini meliputi daerah yang berbukit-bukit, dengan puncak tertinggi pada gunung Slamet, terletak di sisi utara karesidenan ini, sementara di bagian selatan terdapat sedikit bukit-bukit berkapur, dan dataran rendah yang membentang luas. Di Karesidenan ini terdapat banyak aliran sungai, dan sebagian besar sungai-sungai itu bermuara di aliran Sungai Serayu yang merupakan sungai terpanjang dan terbesar di wilayah ini, Sungai Serayu bermata air di gunung Prahu di Banjarnegara dan bermuara di pantai Selatan. Sepanjang daerah aliran sungai Serayu dan anak-anak sungainya, merupakan lembah yang subur. Kesuburan tanah itu terjadi karena sungaisungai yang mengalir membawa sedimen yang dapat menjadikan tanah di aliran sungai menjadi subur (Boomgard, 1997 : 29). Keadaan lingkungan alam yang subur seperti itu merupakan daya dukung bagi penduduk yang tinggal di daerah itu, untuk dapat hidup dengan sejahtera. Di satu sisi adanya aliran sungai serayu membuat tanah di sepanjang aliran sungai menjadi subur, sehingga tidak mengherankan jika di sana banyak terdapat sawah-sawah dan pemukiman penduduk. Di sisi lain keberadaan Sungai Serayu yang yang membelah daerah Banyumas terutama bagian timur, mengakibatkan sebagian daerah yang subur ini terisolir, karena sulitnya transportasi akibat terhalang oleh aliran sungai yang cukup besar.

Eksploitasi alam memang bukan satu-satunya penyebab kerusakan alam, tetapi pertumbuhan penduduk telah memaksa manusia memperluas areal pertanian. Perluasan itu dilakukan dengan cara mengorbankan areal lain seperti hutan dibabat dan tanahnya dicetak menjadi lahan persawahan. Terlebih lagi di banyumas yang secara umum tanahnya subur, maka eksploitasi untuk kepentingan ekonomi lebih mencuat dibanding pelestarian alam. Hal ini tampak sejak pemodal asing pada tahun 1870 mulai menanamkan modalnya di Hindia Belanda, maka di Banyumas dibuka perkebunan tembakau, kopi, dan tebu.

Pembukaan usaha perkebunan itu mengakibatkan terjadinya perubahan lingkungan, yang diakibatkan oleh perluasan lahan perkebunan, terutama perkebunan tebu. Tanaman tebu memerlukan air dalam jumlah yang banyak 
manakala tebu masih muda, hal ini sama dengan kebutuhan air pada tanaman pangan padi. Dengan demikian penggusuran lahan pertanianpun tak dapat dihindari. Pertanian bagi masyarakat pada awalnya hanyalah bersifat subsistence dan jauh dari kepentingan pasar, sementara penanaman tebu berorientasi eksport. Dua jenis tanaman dengan orientasi penanaman yang berbeda, tetapi memerlukan lahan yang sama, berpotensi untuk timbulnya konflik kepentingan. Penanaman tebu bersekala besar tentu memerlukan lahan yang luas, sehingga penanaman tebu tidak cukup hanya dengan menggusur padi, tetapi juga membuka areal baru. Perluasan lahan perkebunan dilakukan oleh perusahaan dengan jalan menyewa tanah kepada penduduk secara individual, dan atau menyewa dari pemerintah. Tanah pemerintah. Pada umumnya tanah pemerintah yang disewakan masih berupa hutan yang belum digarap. Di Karesidenan Banyumas tanah yang disewakan kepada perusahaan perkebunan terletak baik di daerah Banyumas utara maupun selatan selatan (Gulik, MVO, Juni 1930).

Meningkatnya populasi tentu membutuhkan tempat untuk pemukiman, dan lahan pertanian, sementara dibukanya perusahaan perkebunan tentu mengakibatkan meningkatnya kebutuhan lahan penanaman. Salah-satunya kemungkinan untuk memperluas lahan adalah membuka hutan, di samping rekayasa sumber air, agar dapat mengairi lahan tegalan. Akan tetapi untuk daerah Banyumas kemungkinan yang disebut terakhir dapat diabaikan, kecuali di daerah Cilacap bagian barat, mengingat kebutuhan lahan telah tercukupi di daerah yang airnya melimpah sepanjang tahun. Seperti pada umumnya daerah Banyumas curah hujan cukup tinggi sehingga menjamin tercukupinya kebutuhan air baik di musim penghujan maupun kemarau (Pauwert, MVO, 24 Oktober 1925).

Secara umum lahan di daerah Banyumas dapat dibagi menjadi lahan pertanian/perkebunan, tegalan, hutan dan, pemukiman. Keberadaan hutan dari tahun ke tahun semakin berkurang, sebaliknya lahan pemukiman, perkebunan, dan pertanian semakin bertambah. Meningkatnya luas lahan tersebut sejalan dengan meningkatnya kebutuhan lahan pertanian dan perkebunan, baik oleh penduduk maupun oleh perusahaan perkebunan. Pembukaan hutan oleh penduduk, untuk kepentingan pertanian dan pemukiman seperti yang terjadi di daerah Cilacap barat (Helsdingen, MVO, 14 Mei 1928). Luas lahan penanaman tebu di Banyumas di tahun 1860 tercatat hanya seluas 227 ha, dan tahun 1922 luas penanaman tebu telah mencapai 4.882 ha (Schaik, 1986 : 49). 
Perluasan lahan dengan cara membuka hutan, akan berkibat pada perubahan lingkungan dan melemahnya daya dukung alam bagi kehidupan manusia. Artinya perubahan itu dapat dipandang negative dari sisi pelestarian. Akan tetapi di sisi lain pembukaan lahan berarti berkembangnya dunia usaha, khususnya perkebunan. Sampai pada tahun 1928 tercatat enam perusahaan besar yang bergerak dalam bidang perkebunan tebu beroperasi di Karesidenan Banyumas. Perusahaan-perusahaan itu adalah perkebunan Klampok, Bojong, Kalibagor, Kalirejo, Purwokerto, dan Majenang (Zandveld, MVO, 4 Juli 1922., lihat juga Helsdingen, MVO, 14 Mei 1928). Pembukaan usaha perkebunan tebu tentu dilengkapi dengan pabrik pengolah tebu menjadi gula, dan pabrik tentu akan ditempatkan ditempat yang strategis. Strategis dalam arti ketersediaan tenaga kerja, sarana dan prasarana transportasi. Ketersediaan tenaga kerja artinya usaha yang dibuka akan dapat berlangsung, sedang transportasi memudahkan akses dari pabrik menuju pelabuhan dan sebaliknya untuk mengangkut hasil produksi, serta memudahkan pengangkutan bahan mentah dari lahan penanaman menuju pabrik. Akan tetapi sarana dan prasarana transportasi masih sangat terbatas. Sampai tahun 1922 hanya ada satu jembatan untuk menyeberangi Sungai Serayu, yaitu jembatan yang berada di dekat kota Banyumas (Zandveld, MVO, 4 Juli 1922). Sehubungan dengan itu, maka pihak perusahaanlah yang mengadakannya, dan sebagai imbalan pengadaan sarana dan prasarana itu pemerintah memberikan konsesi yang dapat dipergunakan sebagai lahan penanaman. Pengadaan dan pembangunan sarana dan prasarana mempunyai arti penting bagi Karesidenan Banyumas, terutama dalam hal membuka isolasi daerah Banyumas. Baik trem maupun pembangunan jalan dan jembatan pada akhirnya tidak hanya dipergunakan untuk kepentingan perusahaan itu sendiri, tetapi juga dipergunakan oleh masyarakat umum dan pemerintah.

\section{Penduduk dan Budaya Banyumas}

Penduduk Banyumas pada umumnya bermukim disepanjang aliran sungai, hal ini berkaitan erat dengan pertanian yang menjadi mata pencaharian pokok penduduk pada umumnya. Oleh karenanya pilihan tinggal disepanjang aliran sungai didasarkan atas pertimbangan kesuburan tanahnya, yang memberi jaminan keberhasilan dalam bercocoktanam. Produksi pertanian pada setiap panen selalu melimpah, tetapi hasil bumi yang dihasilkan sulit untuk dijual, dan jika laku harganya rendah (Helsdingen, MVO, 14 Mei 1928). Di 
Tahun 1900 penduduk banyumas hanya berjumlah 1.361 .260 orang sudah termasuk orang Belanda dan timur asing seperti Arab dan Cina. Jumlah ini dengan cepat berkembang dan dalam empat dasa warsa kemudian yaitu pada tahun 1940 tercatat jumlah penduduk di Banyumas telah mencapai hampir dua kali lipat yaitu 2.506 .880 orang (Boomgard dan A.J. Gooszen, 1991 : 101-102). Peningkatan jumlah penduduk yang begitu pesat pada quarter pertama abad ke-20 dimungkinkan oleh adanya peningkatan tingkat kesehatan karena adanya ilmu kedokteran modern, semakin luasnya pasar dan kesempatan kerja di luar pertanian (Hayami dan Masao Kikuchi, 1987 : 267).

Meluasnya pasar dan kesempatan kerja di daerah Banyumas terjadi sebagai akibat masuknya perusahaan perkebunan, terutama perkebunan tebu dengan industri gulanya. Berdirinya pabrik gula tentu memerlukan tenaga kerja, tetapi tenaga kerja yang dibutuhkan tidak sepenuhnya terpenuhi oleh penduduk setempat di sekitar pabrik. Artinya Di daerah di mana pabrik didirikan, tersedia lapangan pekerjaan, dan "ibarat ada gula ada semut" terbukanya lapangan pekerjaan menimbulkan migrasi masuk ke daerah perkebunan. Arus migrasi dari daerah banyumas terjadi karena tidak semua desa di Karesidenan Banyumas mempunyai lahan yang subur, sehingga di musim kering mereka mencari nafkah dengan bekerja sebagai buruh di daerah perkebunan. Di masa tunggu dan atau pada musim kering tidak ada yang bisa dikerjakan, sehingga sebagian penduduk untuk sementara bekerja di berbagai daerah lain, dan kembali pada saat musim panen tiba, atau di awal musim penghujan berikutnya (Dina Dwikurniarini, 1999 : 58).

Tersedianya sarana dan prasarana transportasi berupa jalan raya, trem dan kereta api, memperlancar arus keluar dan masuk dari dan ke Banyumas, dan dari kabupaten ke kabupaten lain di Karesidenan Banyumas. Perpindahan penduduk seperti itu bahkan telah terjadi sejak awal dibukanya perkebunan swasta di awal kuarter terakhir abad ke-19. Pada tahun 1878 orang yang meningggalkan Banyumas tercatat berjumlah 7.698 jiwa. Sebaliknya tersedianya lapangan pekerjaan di daerah perkebunan di Banyumas juga menimbulkan arus migrasi masuk ke daerah-daerah perkebunan. Pada tahun 1875 tercatat 3.908 jiwa dari daerah Bagelen masuk ke daerah Banyumas (Arsip Banjoemas no. 18.1.). Berkaitan dengan arus migrasi ini Boomgard dan Gooszen dalam Population Trends 1795-1942 menyebutkan ada sepuluh daerah tujuan migrasi penduduk Banyumas yaitu, Priangan, Kedu, Pekalongan, Batavia, Buitenzorg (Bogor), Semarang, Yogyakarta, Cirebon, Besuki, dan 
Malang yang seluruhnya mencapai sejumlah 66.084 jiwa (1991 : 181-182). Selain migrasi ke daerah lain di Jawa, terdapat pula migrasi dengan tujuan ke luar Jawa, seperti ke Sumatera dan Sulawesi (Dina Dwikurniarini, 1999 : 58). Akan tetapi sayang agak sulit menemukan angka-angka pasti bagi mereka yang bermigrasi ke luar Jawa, hal ini disebabkan sumber di daerah tujuan tidak merinci asal buruh, mereka hanya disebut sebagai tenaga kerja dari Jawa.

Migrasi baik masuk dan keluar tentu mempengaruhi angka jumlah dan kepadatan penduduk daerah Banyumas. Banyaknya orang dari luar masuk ke daerah Banyumas, dengan sendirinya meningkatkan pula jumlah dan kepadatan penduduk di daerah itu, namun demikian peningkatan jumlah dan kepadatan ini tidak terjadi merata di seluruh Banyumas. Penduduk terpusat di daerahdaerah subur, di pusat-pusat kegiatan ekonomi, atau dipinggir jalan yang ramai dengan lalu-lalang orang bepergian. Dengan demikian pertumbuhan penduduk di Karesidenan Banyumas terjadi karena meluasnya perkebunan dan meningkatnya industri gula. Seperti juga di Di wilayah karesidenan lain di Jawa, daerah beroperasinya perusahaan perkebunan dan industri lapangan kerja meningkat, dan sejalan dengan itu maka kesejahteraan pendudukpun dengan sendirinya meningkat pula. Kesejahteraan mengakibatkan tingkat kesehatan meningkat, sehingga angka mortalitas menurun, sementara angka kelahiran meningkat. Di samping itu pusat kegiatan ekonomi, menjadi daya tarik bagi penduduk dari luar daerah, mereka masuk ke daerah yang menjadi pusat kegiatan ekonomi untuk bekerja dan meningkatkan taraf kesejahteraan keluarganya.

Penduduk asli Banyumas adalah orang suku Jawa dengan sub kultur Banyumas. Sub kultur Banyumas sesungguhnya dalam berbagai hal boleh dikata tidak ada bedanya dengan kultur jawa pada umumnya. Budaya Banyumasan sebetulnya dalam berbagai hal cenderung mengikuti budaya yang berpusat di Kraton Kasunanan Surakarta, Hanya saja dalam aplikasinya dalam kehidupan mengalami penyesuaian dengan karakter orang Banyumas. Tata cara pengantin misalnya tidak berbeda dengan yang berada di Surakarta. Begitu pula dalam adat bagi waris berlaku pula pembagian sak pikulan (dua bagian) untuk anak laki-laki, dan sak gendongan (satu bagian) untuk anak perempuan. Artinya antara anak laki-laki dan perempuan dibedakan dalam menerima warisan yaitu dua banding satu. Bedanya dengan orang Jawa di daerah Yogyakarta dan Surakarta terletak pada dialek bahasanya yang ditelinga orang dari luar Banyumas terasa kasar, dan lucu. 
Cablaka sebuah kata dari bahasa Jawa, Kurang lebih mempunyai konotasi terus terang, apa adanya, tidak ada yang disembunyikan, dan lebih jauh dapat pula dipahami sebagai penuh tanggungjawab. Implementasinya dalam kehidupan tentu kata ini tidak semudah mengucapkannya, karena dalam kata ini terkandung sejumlah konsekwensi yang tidak ringan, yakni kerelaan, ketekunan, dan kejujuran dalam setiap kata yang diucapkan maupun dalam tingkah laku. Ungkapan ini kemudian menjadi tuntunan masyarakat jawa penutur dialek Banyumas asli, dan dengan ungkapan itu diharapkan dapat menjadi pegangan perilaku setiap insan yang mengaku dirinya orang Banyumas dan pendukung sub kultur Banyumasan. Hal ini boleh dikatakan menjadi nilai lebih bagi orang Banyumas, walaupun dialek bahasanya yang sangat khas itu sering dijadikan bahan olok-olok, atau bahan gurauan termasuk oleh para komedian di atas panggung.

\section{Perkembangan Ekonomi}

Seperti telah disebut di bagian terdahulu bahwa masyarakat Banyumas adalah masyarakat agraris, yang berarti perekonomian keluarga bertumpu pada pertanian. Keluarga petani dapat hidup dengan bekerja di lahannya sendiri, ataupun mengerjakan lahan milik orang lain, dengan bagi hasil. Seorang kepala keluarga yang bekerja di lahan pertanian dengan dibantu seluruh anggota keluarganya, telah dapat mencukupi kebutuhan konsumsi keluarga. Di daerah yang subur bahkan hasil pertanian melebihi kebutuhan konsumsi keluarga. Kelebihan itu tidak dijual, tetapi disimpan untuk benih di masa tanam berikutnya, atau juga untuk berjaga-jaga jika terjadi kekeringan, atau gagal panen. Cara ini telah ditempuh sejak nenek moyang mereka, yang memang tidak mengenal system ekonomi uang, dan mata uang dikenal setelah Belanda secara intensif mengeksploitasi pedalaman (Burger, 1977: 10). Sampai awal abad ke-20 uang merupakan sesuatu yang langka di Karesidenan Banyumas, hanya desa-desa di daerah-daerah perkebunan saja masyarakat mengenal uang (Helsdingen, MVO, 14 Mei 1928).

Sebelum tahun 1870 yang secara resmi merupakan tahun berakhirnya tanam paksa, masyarakat Jawa pada umumnya adalah masyarakat agraris dengan kecenderungan pertumbuhan penduduk yang tinggi. Demikian pula yang terjadi di Karesidenan Banyumas, luas lahan pertanian di Karesidenan Banyumas pada waktu itu telah mencapai 76.986 bau atau sekitar 5.460 ha yang menghasilkan 1.836,287 pikul padi (Dina Dwikurniarini, 1999 : 69). 
Akan tetapi seiring dengan meningkatnya jumlah penduduk maka teori involusi pertanian Geertz berlaku di Banyumas. Di daerah dengan lahan basah, pertambahan penduduk berarti tambahan tenaga kerja di lahan persawahan, sampai pada akhirnya masukan tenaga kerja tidak lagi sejalan dengan peningkatan produksi, sehingga terjadi proses pemiskinan bersama.

Memasuki masa liberal, sejalan dengan masuknya usaha perkebunan yang juga membutuhkan lahan, maka lahan penanaman yang ada diperluas, kecuali daerah Cilacap. Keberadaan perkebunan dan industri di satu sisi menciptakan lapangan pekerjaan bagi penduduk di sekitarnya, baik sebagai buruh di perkebunan dan pabrik, maupun sebagai supplier barang-barang kerajinan yang diperlukan oleh pabrik, seperti tali, atau keranjang. Di sisi yang lain penduduk terpaksa merelakan sebagian lahan pertaniannya untuk ditananami tebu, walaupun untuk itu para petani memperoleh kompensasi berupa uang sewa. Akan tetapi penerimaan itu seolah tidak berarti, karena besarnya pajak yang harus disetorkan pada pemerintah.

Di masa lampau tenaga kerja dari daerah Karesidenan Banyumas banyak dicari oleh pengusaha-pengusaha Belanda, hal ini disebabkan tenaga kerja dari daerah Banyumas dikenal mempunyai etos kerja yang baik. Etos kerja itu memang didasari oleh nilai-nilai yang terkandung dari ungkapan cablaka yang memang telah melekat pada kebanyakan orang Banyumas. Selain itu mereka sadar, bahwa mereka bekerja bahkan terpaksa merantau sematamata disebabkan oleh keinginan untuk merubah nasib, dan meningkatkan kesejahteraan keluarga. Hal tersebut merupakan pemacu tumbuhnya etos kerja yang baik di kalangan orang banyumas.

Pada pola pertanian subsistem pekerjaan memang melibatkan seluruh anggota keluarga. Kebersamaan dan ketekunan penduduk Karesidenan Banyumas dalam bekerja terlihat dari aktivitasnya sehari-hari. Setiap hari sejak pagi kaum laki-laki telah berkutat di sawah, sementara para wanita menyiapkan makanan, dan anak-anak menggembalakan ternak sambil mencari rumput. Ketekunan dalam bekerja itu menghasilkan melimpahnya hasil bumi, tetapi hasil bumi tersebut harganya rendah, dan penjualannya sangat sulit (Helsdingen, MVO, 14 Mei 1928). Kesulitan menjual hasil bumi lebih disebabkan oleh kelangkaan transportasi dari daerah penghasil menuju pasar, sehingga biaya angkut menjadi tinggi. Kemudian karena harga hasil bumi di pasar tidak mungkin dinaikan, maka para pedagang menekan harga beli di daerah penghasil serendahmungkin. 
Persoalan ketiadaan jalan yang menghubungkan daerah satu dan yang lain di karesidenan Banyumas mengakibatkan sebagian daerah di wilayah Banyumas terisolasi atau terpencil. Para pejabat yang bertugas di karesidenan ini sadar bahwa ketiadaan sarana dan prasarana transportasi menjadi hambatan baik dalam hal pemerintahan, maupun dalam hal pengembangan daerah. Oleh sebab itu para bupati mengusulkan pembangunan jalan yang menghubungkan daerah kabupaten satu dan yang lain (lihat MVO, Residen Banyumas, 1922, 1925, dan 1928). Cara lain yang ditewmpuh oleh para pejabat di Karesidenan Banyumas dalam usahanya membuka isolasi itu adalah dengan cara bersinergi dengan pihak perusahaan dan rakyat. Pemerintah memberikan lahan bagi perusahaan, sedang perusahaan membiayai pembangunan jalan, dan rakyat menyediakan tenaga dengan melakukan gugur gunung. Kebijakan ini diambil pemerintah karena semua pihak akan mengambil keuntungan dari pembangunan jalan yang membuka keterpencilan daerah. Terbukanya akses menuju daerah-daerah di karesidenan ini secara langsung meningkatkan perekonomian penduduk.

Desa-desa di daerah perkebunan disebutkan bahwa tingkat ekonomi dan kesejahteraan penduduknya sedikit lebih baik dibanding desa diluar daerah operasi perkebunan. Akan tetapi tidak berarti di daerah perkebunan tidak terjadi resistensi, penduduk di daerah perkebunan Klampok dan Kalirejo misalnya, sering melakukan pembakaran tanaman tebu (Pauwert, MVO, 24 Oktober 1925). Pembakaran ini terjadi karena penduduk merasa diperlakukan tidak adil oleh pihak pabrik gula. Ketidak adilan itu terutama dalam hal pembagian penggunaan air, dan uang ganti rugi akibat keterlambatan tebang. Bagi pemerintah persoalan ini hanya dipandang sebagai salah pengertian saja, sehingga pemerintah tidak mengambil tindakan atas peristiwa-peristiwa itu. Pemerintah bahkan menganjurkan agar kedua pihak membangun saling pengertian, seperti yang terjadi di Pabrik Gula Kalibagor dan Purwokerto. Ternyata cara itu cukup efektif untuk mencegah terjadinya tindakan anarkhis penduduk.

\section{E. Kesimpulan}

Pola tanggapan terhadap pertambahan jumlah penduduk, system bagi waris, dan masuknya perkebunan tebu semakin meminggirkan penduduk pribumi. Posisi penduduk tidak memungkinkan bersaing dengan kekuatan modal besar kaum pengusaha swasta asing. Di daerah Karesidenan Banyumas 
penduduk yang menggantungkan hidupnya pada pertanian, terpaksa berbagi lahan dengan pengusaha perkebunan.

Daerah Karesidenan Banyumas yang pada awalnya merupakan daerah yang terpencil, terisolasi oleh ketiadaan sarana prasarana jalan. Lambat laun isolasi dibuka, sehingga daerah yang terpencil itu berkembang menjadi pusatpusat kegiatan ekonomi yang ramai. Akses menuju daerah Karesidenan ini semakin terbuka dengan adanya jalan raya yang menghubungkan daerah satu dan yang lain di Karesidenan Banyumas. Perkembangan itu tentu tidak akan terjadi tanpa keterlibatan rakyat dalam pembangunan fisik, dengan memanfaatkan perusahaan yang beroperasi di daerah itu sebagai sumber dana. Kerelaan penduduk mengambil bagian dalam pembangunan terjadi karena adanya keinginan dari penduduk itu sendiri untuk meningkatkan tingkat kesejahteraan keluarganya.

Keinginan untuk meningkatkan kesejahteraan keluarga merupakan bukti rasa tanggungjawab setiap kepala keluarga terhadap seluruh anggota keluarganya. Rasa tanggungjawab itu ditunjukkan dengan cara tekun bekerja baik di lahannya sendiri atau bekerja di lahan orang lain, bekerja di daerahnya sendiri atau bekerja di perantauan. Keikutsertaan penduduk dalam pembangunan fisik berupa jalan raya, jembatan, dan jaringan irigasi, sementara hidupnya berada pada taraf yang rendah, merupakan bukti nyata adanya keralaan, ketekunan, dan rasa tanggungjawab.

Ketiga kata itu merupakan esensi dari ungkapan “cablaka” yang merupakan tongkat bergagang emas, yang menuntun orang Banyumas menjalani hidup. Hal itu terbukti telah menuntun orang Banyumas secara kreatif mampu memanfaatkan tekanan yang menghimpit, menjadi kekuatan dalam pembangunan daerah. Esensi “cablaka” memang tidak diwariskan dengan kata, tetapi disampaikan dari generasi ke generasi dengan keteladanan dalam bertutur dan berperilaku. Keteladanan yang diberikan oleh setiap generasi kepada penerusnya, telah membentuk stereotipe karakter masyarakat Banyumas. Hal tersebut sangat jelas tercermin pada tenaga kerja dengan latar belakang budaya “cablaka” Banyumasan. Etos kerja yang dilatarbelakangi oleh falsafah dan budayanya sendiri, pantas dikembangkan dalam rangka membangkitkan etos kerja yang dilandasi semangat nasionalisme, demi meraih Indonesia yang makmur dan sejahtera. 


\section{Daftar Pustaka}

\section{A. Arsip}

Arsip Banjoemas no. 18.1

Arsip Banjoemas No. 20.16

Gulik, P.J. van, MVO, Gubernur Jawa Tengah Juni 1930

Helsdingen, J.J., MVO, Residen Banjoemas 14 Mei 1928

Pauwert, M.J. van der, MVO, 2 Residen Banjoemas 4 Oktober 1925

Zandveld, M., MVO, Residen Banjoemas 4 Juli 1922

\section{B. Buku}

Boomgard, Peter, dan A.J. Gooszen, (1991), Changing Economy in Indonesia Vol. 11 : Population Trends 1795-1942, Amsterdam : Royal Tropical Institut.

Boomgard, Peter, ed. (1997), Paper Lanscapes : Explorations In The Environmental History of Indonesia, Leiden : KITLV Press.

Burger, D.H., (1977), Perubahan-Perubahan Struktur dalam Masyarakat Jawa, Jakarta : Bhratara.

Dina Dwikurniarini, (1999), "Epidemi Di Karesidenan Banyumas Tahun 1870 - 1940” Thesis, Yogyakarta : Program Pasca Sarjana UGM.

Hayami, Yuyiro, dan Masao Kikuchi, (1987), Dilema Ekonomi Desa Suatu Pendekatan Ekonomi Terhadap Perubahan Kelembagaan di Asia, Jakarta : Yayasan Obor Indonesia.

Kano, Hiroyosi, (1986), “ Sejarah Ekonomi Masyarakat Pedesaan Jawa : Suatu Interpretasi Kembali” dalam Akira Nagazumi, ed. Indonesia Dalam Kajian Sarjana Jepang : Perubahan Sosial Ekonomi Abad XIX \& XX dan Berbagai Aspek Nasionalisme Indonesia, Jakarta : Yayasan Obor Indonesia.

Schaik, Arthur van, (1986), Colonial Control and Peasant Resources in Java : Agricaltural Involution Reconsidered, Amsterdam : Universiteit van Amsterdam. 